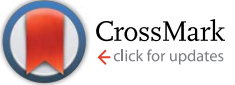

Cite this: RSC Adv., 2015, 5, 11861
Received 2nd October 2014 Accepted 6th January 2015

DOI: 10.1039/c4ra11682h

www.rsc.org/advances

\section{Structure, antimicrobial activity, albumin- and DNA-binding of manganese(II)-sparfloxacinato complexes $\uparrow$}

\begin{abstract}
Marianthi Zampakou, ${ }^{a}$ Sofia Balala, ${ }^{\text {b }}$ Franc Perdih, ${ }^{c}$ Stavros Kalogiannis, ${ }^{\mathrm{b}}$ Iztok Turel ${ }^{\mathrm{c}}$ and George Psomas*a

Manganese(॥) complexes with the quinolone antimicrobial agent sparfloxacin (Hsf) in the absence or presence of the nitrogen-donor heterocyclic ligands 1,10-phenanthroline (phen), 2,2'-bipyridine (bipy), 2,2'-bipyridylamine (bipyam) or pyridine (py) were synthesized and characterized with diverse physicochemical and spectroscopic techniques. The crystal structure of complex $\left[\mathrm{Mn}(\mathrm{sf})_{2}(\mathrm{phen})\right] \cdot 4 \mathrm{MeOH}$ was determined by X-ray crystallography. In the resultant complexes, the deprotonated sparfloxacinato ligands are bidentately bound to manganese(॥) through the pyridone oxygen and a carboxylato oxygen. The antimicrobial activity of the complexes was tested against four different microorganisms (Escherichia coli, Xanthomonas campestris, Staphylococcus aureus and Bacillus subtilis) and was found to be similar to or higher than free Hsf. The binding of the complexes to calf-thymus DNA (CT DNA) was monitored by UV spectroscopy and DNA viscosity measurements, which indicated intercalation as the most possible mode, and the DNA-binding constants of the complexes were calculated. The ability of the complexes to displace ethidium bromide (EB) from the EB-DNA complex was also investigated. Fluorescence emission spectroscopy was used to evaluate the interaction of the complexes with human or bovine serum albumin proteins revealing their binding with relatively high binding constant values.
\end{abstract}

\section{Introduction}

Manganese is among the most significant biometals mainly due to its presence in the active centre of many enzymes exhibiting diverse functionality. ${ }^{\mathbf{1 , 2}}$ The anticancer agent SC-52608 and the MRI contrast agent Teslascan are the only manganesecontaining compounds used in medicine up to now. ${ }^{3}$ Within the context of the attempt of bioinorganic chemists to develop novel metallodrugs, a lot of manganese compounds were tested for their in vitro bioactivity. The obtained preliminary results were quite interesting since some of the resultant manganese complexes exhibited noteworthy anticancer, ${ }^{4-6}$ antifungal ${ }^{7}$ and antimicrobial activity. The ligands of the manganese complexes showing antimicrobial activity present an interesting diversity; they may be drugs such as monensin $\mathrm{A},{ }^{8}$ thiopental sodium, ${ }^{9}$

${ }^{a}$ Department of General and Inorganic Chemistry, Faculty of Chemistry, Aristotle University of Thessaloniki, GR-54124 Thessaloniki, Greece. E-mail: gepsomas@ chem.auth.gr; Fax: +30 2310997738; Tel: +30 2310997790

${ }^{b}$ Department of Nutrition and Dietetics, Faculty of Agriculture, Food Technology and Nutrition, Alexander Technological Educational Institution, Sindos, Thessaloniki, Greece

${ }^{c}$ Faculty of Chemistry and Chemical Technology, University of Ljubljana, Vecna pot 113, 1000 Ljubljana, Slovenia

$\dagger$ Electronic supplementary information (ESI) available. CCDC 1026288. For ESI and crystallographic data in CIF or other electronic format see DOI: 10.1039/c4ra11682h chloramphenicol $^{\mathbf{1 0}}$ or enrofloxacin ${ }^{\mathbf{1 1}}$ or ligands such as Schiff bases, ${ }^{12-15}$ derivatives of coumarin ${ }^{16,17}$ and 8-hydroxyquinoline, ${ }^{18}$ carbazone derivatives, ${ }^{19,20}$ carboxylic acids, ${ }^{21,22}$ hydrazides, ${ }^{23,24}$ and macrocycles. ${ }^{25,26}$

Quinolones are a group of synthetic antibacterial agents used in the treatment of many infections..$^{27,28}$ The main targets of quinolones are the participating in the DNA-replication enzymes gyrase (type II topoisomerases) and topoisomerase IV. ${ }^{29,30}$ Diverse metal complexes of quinolones have been reported exhibiting enhanced antiproliferative ${ }^{31-33}$ and antibacterial $^{34,35}$ activity and increased binding affinity for $\mathrm{DNA}^{36-38}$ in comparison to the corresponding free quinolones. ${ }^{39}$ Sparfloxacin (Hsf) $\dagger$ (Fig. 1) is a third-generation quinolone, it is active against Gram-positive species such as Staphylococci and is used to treat chronic bronchitis and community-acquired pneumonia. ${ }^{28,29}$ The major advantages of Hsf are the good<smiles>CC1CN(c2c(F)c(N)c3c(=O)c(C(=O)O)cn(C4CC4)c3c2F)CC(C)N1</smiles>

Fig. 1 Sparfloxacin (Hsf). 
bioavailability and the long half-life which permit once-daily dosing, thus contributing to improved adherence to therapy and cost-effectiveness. ${ }^{40}$ In the literature, a $\mathrm{Zn}(\mathrm{II}),{ }^{41}$ two Ni(II) ${ }^{42,43}$ and three $\mathrm{Cu}(\mathrm{II})^{\mathbf{4 4 , 4 5}}$ sparfloxacinato complexes have been structurally characterized and have exhibited enhanced biological behaviour in comparison to free Hsf. ${ }^{39}$

Taking into consideration the wide-spread use of quinolones in medicine, the potential synergetic effects that occur in the presence of metals and as a continuation of our research, ${ }^{11,31-34,37-39,41-44}$ the interaction of manganese(II) with the third-generation quinolone antimicrobial drug sparfloxacin was investigated in the presence or absence of nitrogen-donor ligands such as 1,10-phenanthroline (phen), 2,2'-bipyridine (bipy), 2,2'-bipyridylamine (bipyam) or pyridine (py). The resultant complexes $\left[\mathrm{Mn}(\mathrm{sf})_{2}(\mathrm{phen})\right] \cdot 4 \mathrm{MeOH} \quad(\mathbf{1} \cdot 4 \mathrm{MeOH})$, $\left[\mathrm{Mn}(\mathrm{sf})_{2} \text { (bipy)] (2), [Mn(sf) }\right)_{2}$ (bipyam) $](3),\left[\mathrm{Mn}(\mathrm{sf})_{2}(\mathrm{py})_{2}\right](4)$ and $\left[\mathrm{Mn}(\mathrm{sf})_{2}\left(\mathrm{H}_{2} \mathrm{O}\right)_{2}\right](5)$ were characterized with diverse physicochemical and spectroscopic techniques and the crystal structure of $\left[\mathrm{Mn}(\mathrm{sf})_{2}\right.$ (phen) $] \cdot 4 \mathrm{MeOH}(\mathbf{1} \cdot 4 \mathrm{MeOH})$ was determined by X-ray crystallography. The biological impact of complexes 1-5 was evaluated in relevance to: (i) their antimicrobial activity by determining the minimum inhibitory concentration (MIC) against four microorganisms (i.e. Escherichia coli NCTC 29212 (E. coli), Xanthomonas campestris ATCC 1395 (X. campestris), Staphylococcus aureus ATCC 6538 (S. aureus) and Bacillus subtilis ATCC 6633 (B. subtilis)), (ii) their interaction with calf-thymus (CT) DNA investigated by UV spectroscopy and viscosity measurements in order to explore the binding mode and strength, (iii) their ability to displace the classical DNA-intercalator ethidium bromide (EB) from its CT DNA-EB complex as a means to investigate the existence of a potential intercalation monitored by fluorescence emission spectroscopy and (iv) their affinity to bovine (BSA) and human (HSA) serum albumins investigated by fluorescence spectroscopy, since the binding to these proteins which are involved in the transport of metal ions and compounds through the bloodstream may provide important information for the transportation of the compounds within the body, as a first means to potential applications. ${ }^{46}$

\section{Experimental}

\section{Materials and instrumentation}

Sparfloxacin, $\mathrm{MnCl}_{2} \cdot 4 \mathrm{H}_{2} \mathrm{O}$, bipy, phen, bipyam, py, $\mathrm{KOH}, \mathrm{NaCl}$, trisodium citrate, CT DNA, BSA, HSA and EB were purchased from Sigma-Aldrich Co and all solvents were purchased from Merck. All the chemicals and solvents were reagent grade and were used as purchased.

DNA stock solution was prepared by dilution of CT DNA to buffer (containing $15 \mathrm{mM}$ trisodium citrate and $150 \mathrm{mM} \mathrm{NaCl}$ at $\mathrm{pH}$ 7.0) followed by exhaustive stirring for three days, and kept at $4{ }^{\circ} \mathrm{C}$ for no longer than a week. The stock solution of CT DNA gave a ratio of UV absorbance at 260 and $280 \mathrm{~nm}\left(A_{260} / A_{280}\right)=$ 1.86 , indicating that the DNA was sufficiently free of protein contamination. ${ }^{47}$ The concentration of the initial DNA solution per base pairs was determined by the UV absorbance at $260 \mathrm{~nm}$ after $1: 20$ dilution using $\varepsilon=6600 \mathrm{M}^{-1} \mathrm{~cm}^{-1} \cdot{ }^{48}$
Infrared (IR) spectra (400-4000 $\left.\mathrm{cm}^{-1}\right)$ were recorded on a Nicolet FT-IR 6700 spectrometer with samples prepared as $\mathrm{KBr}$ disk. UV-visible (UV-vis) spectra were recorded as nujol mulls and in solution at concentrations in the range $10^{-5}$ to $10^{-3} \mathrm{M}$ on a Hitachi U-2001 dual beam spectrophotometer. Room temperature magnetic measurements were carried out on a magnetic susceptibility balance of Sherwood Scientific (Cambridge, UK) by the Faraday method. C, $\mathrm{H}$ and $\mathrm{N}$ elemental analysis were performed on a Perkin-Elmer 240B elemental analyzer. Molar conductivity measurements of $1 \mathrm{mM}$ DMSO solutions of the complexes were carried out with a Crison Basic 30 conductometer. Fluorescence spectra were recorded in solution on a Hitachi F-7000 fluorescence spectrophotometer. Viscosity experiments were carried out using an ALPHA L Fungilab rotational viscometer equipped with an $18 \mathrm{~mL}$ LCP spindle.

\section{Synthesis of the complexes}

Synthesis of $\left[\mathrm{Mn}(\mathbf{s f})_{2}(\mathrm{phen})\right] \cdot 4 \mathrm{MeOH}, 1 \cdot 4 \mathrm{MeOH}$. A methanolic solution $(10 \mathrm{~mL})$ of $\mathrm{Hsf}(0.4 \mathrm{mmol}, 157 \mathrm{mg})$ and $\mathrm{KOH}(0.4$ mmol, $22 \mathrm{mg}$ ), after a $30 \mathrm{~min}$ stirring, was added simultaneously with a methanolic solution of phen $(0.2 \mathrm{mmol}, 36 \mathrm{mg})$ to a methanolic solution ( $5 \mathrm{~mL})$ of $\mathrm{MnCl}_{2} \cdot 4 \mathrm{H}_{2} \mathrm{O}(0.2 \mathrm{mmol}, 40$ $\mathrm{mg}$ ) and the reaction mixture was stirred for $30 \mathrm{~min}$ and left for slow evaporation. Pale yellow well-formed crystals of $\left[\mathrm{Mn}(\mathrm{sf})_{2}\right.$ (phen)] $4 \mathrm{MeOH}, 1 \cdot 4 \mathrm{MeOH}(150 \mathrm{mg}$, yield: 65\%) suitable for $\mathrm{X}$-ray structure determination, were collected after a few days. Anal. calcd for $\mathrm{C}_{54} \mathrm{H}_{66} \mathrm{~F}_{4} \mathrm{MnN}_{10} \mathrm{O}_{10}(\mathrm{MW}=1146.11) \mathrm{C} 56.59, \mathrm{H}$ 5.80, N 12.22\%; found: C 56.45, H 5.68, N 12.28\%. IR: $\nu_{\max }$, $\mathrm{cm}^{-1} ; \nu(\mathrm{C}=\mathrm{O})_{\text {pyridone, }} 1631$ (very strong (vs)); $\nu_{\text {asym }}\left(\mathrm{CO}_{2}\right), 1604$ (strong (s)); $\nu_{\text {sym }}\left(\mathrm{CO}_{2}\right), 1371(\mathrm{~s}) ; \Delta=\nu_{\text {asym }}\left(\mathrm{CO}_{2}\right)-\nu_{\text {sym }}\left(\mathrm{CO}_{2}\right)=$ $233 \mathrm{~cm}^{-1}$ (KBr disk); UV-vis: $\lambda, \mathrm{nm}\left(\varepsilon, \mathrm{M}^{-1} \mathrm{~cm}^{-1}\right)$ as nujol mull: 375 (shoulder (sh)), 306; in DMSO: 380 (400), 304 (10 400). $\mu_{\text {eff }}=$ $5.97 \mathrm{BM}$. The complex is soluble in DMF and DMSO $\left(\Lambda_{\mathrm{M}}=10\right.$ $\mu \mathrm{S} \mathrm{cm}^{-1}$, in $1 \mathrm{mM}$ DMSO solution).

Synthesis of complexes $\left[\mathrm{Mn}(\mathbf{s f})_{2}(\right.$ bipy $\left.)\right], 2,\left[\mathrm{Mn}(\mathbf{s f})_{2}(\right.$ bipyam $\left.)\right]$, 3, and $\left[\mathbf{M n}(\mathbf{s f})_{2}(\mathbf{p y})_{2}\right], \mathbf{4}$. Complexes $\mathbf{2 - 4}$ were prepared in a similar way to complex $\mathbf{1}$ with the use of the corresponding nitrogen-donor ligand.

$\left[\mathrm{Mn}(\mathrm{sf})_{2}(\right.$ bipy $\left.)\right]$, 2. A methanolic solution $(5 \mathrm{~mL})$ of bipy $(0.2$ mmol, $31 \mathrm{mg}$ ) was used instead of phen. A yellowish microcrystalline product $\left[\mathrm{Mn}(\mathrm{sf})_{2}\right.$ (bipy)], $2(110 \mathrm{mg}$, yield: $55 \%)$ was collected after three days. Anal. calcd for $\mathrm{C}_{48} \mathrm{H}_{50} \mathrm{~F}_{4} \mathrm{MnN}_{10} \mathrm{O}_{6}$ $(\mathrm{MW}=993.92) \mathrm{C} 58.01, \mathrm{H} 5.07, \mathrm{~N} 14.09 \%$; found: C $57.87, \mathrm{H}$ 4.88, N 13.85\%. IR: $\nu_{\max }, \mathrm{cm}^{-1} ; \nu(\mathrm{C}=\mathrm{O})_{\text {pyridone }} 1632$ (vs); $\nu_{\text {asym }}\left(\mathrm{CO}_{2}\right), 1603(\mathrm{vs}) ; \nu_{\text {sym }}\left(\mathrm{CO}_{2}\right), 1379(\mathrm{vs}) ; \Delta=224 \mathrm{~cm}^{-1}(\mathrm{KBr}$ disk); UV-vis: $\lambda, \mathrm{nm}\left(\varepsilon, \mathrm{M}^{-1} \mathrm{~cm}^{-1}\right)$ as nujol mull: 387 (sh), 307, 285; in DMSO: 382 (650), 305 (sh) (9500), 286 (14 500). $\mu_{\text {eff }}=$ 6.01 BM. The complex is soluble in DMF and DMSO $\left(\Lambda_{\mathrm{M}}=14\right.$ $\mu \mathrm{S} \mathrm{cm}^{-1}$, in $1 \mathrm{mM}$ DMSO solution).

$\left[\mathrm{Mn}(\mathrm{sf})_{2}\right.$ (bipyam)], 3. A methanolic solution (5 mL) of bipyam (0.2 mmol, $39 \mathrm{mg}$ ) was used instead of phen. A pale-yellow microcrystalline product $\left[\mathrm{Mn}(\mathrm{sf})_{2}(\right.$ bipyam $\left.)\right], 3$ (120 mg, yield: $60 \%$ ) was deposited after a week. Anal. calcd for $\mathrm{C}_{48} \mathrm{H}_{51} \mathrm{MnN}_{11} \mathrm{O}_{6}$ $(\mathrm{MW}=1008.94) \mathrm{C} 57.14, \mathrm{H} 5.10, \mathrm{~N}$ 15.27\%; found: C 57.27, $\mathrm{H}$ 4.92, N 15.08\%. IR: $\nu_{\max }, \mathrm{cm}^{-1} ; \nu(\mathrm{C}=\mathrm{O})_{\text {pyridone }} 1634$ (vs); 
$\nu_{\text {asym }}\left(\mathrm{CO}_{2}\right), 1598(\mathrm{~s}) ; \nu_{\text {sym }}\left(\mathrm{CO}_{2}\right), 1384(\mathrm{~s}) ; \Delta=214 \mathrm{~cm}^{-1}$ (KBr disk); UV-vis: $\lambda, \mathrm{nm}\left(\varepsilon, \mathrm{M}^{-1} \mathrm{~cm}^{-1}\right)$ as nujol mull: 385 (sh), 309, 275; in DMSO: 380 (750), 308 (11 500), 270 (15 200). $\mu_{\text {eff }}=5.95$ BM. The complex is soluble in DMSO $\left(\Lambda_{\mathrm{M}}=8 \mu \mathrm{S} \mathrm{cm}{ }^{-1}\right.$, in $1 \mathrm{mM}$ DMSO solution).

$\left[\mathrm{Mn}(s f)_{2}(p y)_{2}\right], 4.2 \mathrm{~mL}$ of py were added instead of phen. A pale-yellow microcrystalline product $\left[\mathrm{Mn}(\mathrm{sf})_{2}(\mathrm{py})_{2}\right], 4(125 \mathrm{mg}$, yield: 63\%) was deposited after twenty days. Anal. calcd for $\mathrm{C}_{48} \mathrm{H}_{52} \mathrm{~F}_{4} \mathrm{MnN}_{10} \mathrm{O}_{6}(\mathrm{MW}=995.94) \mathrm{C} 57.89, \mathrm{H} 5.26, \mathrm{~N} 14.06 \%$; found: C 57.71, H 5.12, N 13.91\%. IR: $\nu_{\max }, \mathrm{cm}^{-1} ; \nu(\mathrm{C}=\mathrm{O})_{\text {pyridone, }}$ 1632 (vs); $\nu_{\text {asym }}\left(\mathrm{CO}_{2}\right), 1603(\mathrm{~s}) ; \nu_{\text {sym }}\left(\mathrm{CO}_{2}\right), 1383(\mathrm{~s}) ; \Delta=220 \mathrm{~cm}^{-1}$ (KBr disk); UV-vis: $\lambda, \mathrm{nm}\left(\varepsilon, \mathrm{M}^{-1} \mathrm{~cm}^{-1}\right)$ as nujol mull: 385 (sh), 306, 277; in DMSO: 381 (750), 303 (12 500), 280 (9700). $\mu_{\text {eff }}=5.99 \mathrm{BM}$. The complex is soluble in DMF and DMSO $\left(\Lambda_{\mathrm{M}}=\right.$ $12 \mu \mathrm{S} \mathrm{cm}^{-1}$, in $1 \mathrm{mM}$ DMSO solution).

Synthesis of $\left[\mathbf{M n}(\mathbf{s f})_{2}\left(\mathrm{H}_{2} \mathrm{O}\right)_{2}\right], \mathbf{5}$. Complex 5 was prepared by the addition of a methanolic solution $(10 \mathrm{~mL})$ of $\mathrm{Hsf}(0.4 \mathrm{mmol}$, $157 \mathrm{mg})$ deprotonated by $\mathrm{KOH}(0.4 \mathrm{mmol}, 22 \mathrm{mg})$, after a $30 \mathrm{~min}$ stirring, to a methanolic solution ( $5 \mathrm{~mL})$ of $\mathrm{MnCl}_{2} \cdot 4 \mathrm{H}_{2} \mathrm{O}(0.2$ $\mathrm{mmol}, 40 \mathrm{mg})$. A pale-yellow microcrystalline product $\left[\mathrm{Mn}(\mathrm{sf})_{2}\right.$ $\left(\mathrm{H}_{2} \mathrm{O}\right)_{2}$ ], 5 (115 mg, yield: 65\%) was deposited after a week and collected. Anal. calcd for $\mathrm{C}_{38} \mathrm{H}_{46} \mathrm{~F}_{4} \mathrm{MnN}_{8} \mathrm{O}_{8}(\mathrm{MW}=873.77) \mathrm{C}$ 52.24, H 5.31, N 12.82\%; found: C 52.45, H 5.48, N 12.54\%. IR: $\nu_{\max }, \mathrm{cm}^{-1} ; \nu(\mathrm{C}=\mathrm{O})_{\text {pyridone, }} 1631(\mathrm{vs}) ; \nu_{\text {asym }}\left(\mathrm{CO}_{2}\right), 1607(\mathrm{~s}) ; \nu_{\mathrm{sym}^{-}}$ $\left(\mathrm{CO}_{2}\right), 1380(\mathrm{~s}) ; \Delta=227 \mathrm{~cm}^{-1}$ (KBr disk); UV-vis: $\lambda, \mathrm{nm}\left(\varepsilon, \mathrm{M}^{-1}\right.$ $\mathrm{cm}^{-1}$ ) as nujol mull: 380, 308 (sh), 288; in DMSO: 375 (250), 305 (sh) (3500), 290 (10 500). $\mu_{\text {eff }}=5.93 \mathrm{BM}$. The complex is soluble in DMF and DMSO $\left(\Lambda_{\mathrm{M}}=11 \mu \mathrm{S} \mathrm{cm}^{-1}\right.$, in $1 \mathrm{mM}$ DMSO solution).

\section{X-ray structure determination}

Single-crystal X-ray diffraction data were collected on Agilent Technologies SuperNova Dual diffractometer with an Atlas

Table 1 Crystallographic data for complex $\left[\mathrm{Mn}(\mathrm{sf})_{2}(\right.$ phen)] $\cdot 4 \mathrm{MeOH}$

$\left[\mathrm{Mn}(\mathrm{sf})_{2}(\mathrm{phen})\right] \cdot 4 \mathrm{MeOH}$

$\begin{array}{ll}\text { Empirical formula } & \mathrm{C}_{54} \mathrm{H}_{66} \mathrm{~F}_{4} \mathrm{MnN}_{10} \mathrm{O}_{10} \\ M_{\mathrm{w}} & 1146.11 \\ T, \mathrm{~K} & 293(2) \\ \text { Crystal system } & \text { Orthorhombic } \\ \text { Space group } & \text { Pccn } \\ a(\AA) & 14.9469(5) \\ b(\AA) & 16.0111(5) \\ c(\AA) & 23.5378(6) \\ \alpha\left({ }^{\circ}\right) & 90.00 \\ \beta\left({ }^{\circ}\right) & 90.00 \\ \gamma\left({ }^{\circ}\right) & 90.00 \\ V\left(\AA^{3}\right) & 5633.0(3) \\ Z & 4 \\ D_{\text {calc }}(\mathrm{g} \text { cm } & \\ \mu(\mathrm{mm}) & 1.351 \\ \text { Data collected/unique/[I }>2 \sigma(I)] & 0.313 \\ \text { Restraints/parameters } & 21804 / 6465 / 3788 \\ S & 0 / 366 \\ R_{1}, \mathrm{w} R_{2}[\mathrm{I}>2 \sigma(I)] & 1.024 \\ R_{1}, \mathrm{w} R_{2}(\text { all data) } & 0.0535 / 0.1180 \\ \text { Largest diff. peak/hole }\left(\mathrm{e} \AA^{-3}\right) & 0.1068 / 0.1406 \\ \end{array}$

detector and $\mathrm{Mo}-\mathrm{K}_{\alpha}$ radiation $(\lambda=0.71073 \AA)$ at room temperature. The data were processed using CrysAlis Pro. ${ }^{49}$ Structure was solved by direct methods implemented in SHELXS-97 and refined by a full-matrix least-squares procedure based on $F^{2}$ with SHELXL-97. ${ }^{50}$ All the non-hydrogen atoms were refined anisotropically. Hydrogen atoms were readily located in difference Fourier maps and were subsequently treated as riding atoms in geometrically idealized positions, except in the $\mathrm{NH}$ group where they were refined freely with set isotropic temperature factors $U_{\text {iso }}(\mathrm{H})=1.2 U_{\text {eq }}(\mathrm{N})$. Crystallographic data are listed in Table 1.

\section{Determination of minimum inhibitory concentration}

The antimicrobial activities of the compounds under investigation, Hsf and complexes 1-5, were evaluated by determining the MIC values towards four bacterial species, namely two Gram negative (E. coli NCTC 29212 and X. campestris ATCC 1395) and two Gram positive (S. aureus ATCC 6538 and B. subtilis ATCC 6633). Cultures of the microbial strains were grown on a rich selective agar medium and stored at $4{ }^{\circ} \mathrm{C}$. The selective media used were nutrient agar or broth for B. subtilis and S. aureus, yeast mold agar or broth for $X$. campestris and Luria broth or agar for E. coli. Cells picked from the surface of the stored cultures were used to initiate liquid pre-cultures of the same selective medium at an initial turbidity of roughly 1 McFarland unit. Pre-cultures were incubated for $24 \mathrm{~h}$ in a rotary shaking incubator and subsequently they were used to inoculate the test cultures used for the determination of MIC at an initial turbidity of 0.5 McFarland units. The test cultures consisted of Mueller-Hinton broth (Deben Diagnostics Ltd) containing different concentrations of the compounds. Different concentrations were achieved as follows: the compounds were freshly dissolved in DMSO to a concentration of $5 \mathrm{mg} \mathrm{mL}^{-1}$ and they were diluted by a solution containing $5 \% \mathrm{v} / \mathrm{v}$ DMSO in sterile water, using the method of progressive double dilution. Thus working solutions with decreasing concentrations of the compounds under investigation were achieved. The working solutions were subsequently diluted to the final desired concentration by addition to the growth medium at a proportion of $2: 98$. MIC values were determined as the lowest concentrations of the tested compounds that inhibited visible growth of each respective organism after a $24 \mathrm{~h}$ incubation. ${ }^{51} \mathrm{All}$ test cultures were grown in triplicates and for the determination of MIC, growth had to be inhibited in at least two cultures of the triplicate. Incubation temperature at all stages was $37^{\circ} \mathrm{C}$ except for $X$. campestris that was cultivated at $28{ }^{\circ} \mathrm{C}$.

\section{DNA binding studies}

Study with UV spectroscopy. The interaction of complexes 1-5 with CT DNA was studied using UV spectroscopy in order to investigate the possible binding modes to CT DNA and to calculate the binding constants to CT DNA $\left(K_{\mathrm{b}}\right)$. The UV spectra of CT DNA were recorded for a constant CT DNA concentration in the presence of each complex for diverse $r$ values $(r=$ [complex]/[CT DNA] mixing ratios). The binding constants, $K_{\mathrm{b}}$ (in $\mathrm{M}^{-1}$ ), of the complexes with CT DNA were determined by the 
Wolfe-Shimer equation (eqn $(1))^{52}$ and the plots $\frac{[\mathrm{DNA}]}{\left(\varepsilon_{\mathrm{A}}-\varepsilon_{\mathrm{f}}\right)}$ versus [DNA] using the UV spectra of the compound recorded for a constant concentration in the absence or presence of CT DNA for diverse $r$ values. The Wolfe-Shimer equation is given below:

$$
\frac{[\mathrm{DNA}]}{\left(\varepsilon_{\mathrm{A}}-\varepsilon_{\mathrm{f}}\right)}=\frac{[\mathrm{DNA}]}{\left(\varepsilon_{\mathrm{b}}-\varepsilon_{\mathrm{f}}\right)}+\frac{1}{K_{\mathrm{b}}\left(\varepsilon_{\mathrm{b}}-\varepsilon_{\mathrm{f}}\right)}
$$

where [DNA] is the concentration of DNA in base pairs, $\varepsilon_{\mathrm{A}}=$ $A_{\text {obsd }} /\left[\right.$ compound], $\varepsilon_{\mathrm{f}}=$ the extinction coefficient for the free compound and $\varepsilon_{\mathrm{b}}=$ the extinction coefficient for the compound in the fully bound form. Control experiments with DMSO were also performed and no changes in the spectra of CT DNA were observed.

Viscometry. Viscosity experiments were carried out using an ALPHA L Fungilab rotational viscometer equipped with an 18 mL LCP spindle and the measurements were performed at 100 $\mathrm{rpm}$. The viscosity of DNA $([\mathrm{DNA}]=0.1 \mathrm{mM})$ in buffer solution (150 mM NaCl and $15 \mathrm{mM}$ trisodium citrate at $\mathrm{pH} 7.0$ ) was measured in the presence of increasing amounts of the compounds (up to the value of $r=0.26$ ). All measurements were performed at room temperature. The obtained data are presented as $\left(\eta / \eta_{0}\right)^{1 / 3}$ versus $r$, where $\eta$ is the viscosity of DNA in the presence of the compound, and $\eta_{0}$ is the viscosity of DNA alone in buffer solution.

EB competitive studies with fluorescence spectroscopy. The competitive studies of each complex with EB have been investigated using fluorescence spectroscopy in order to examine whether the compound can displace EB from its DNA-EB complex. The DNA-EB complex was prepared by adding $20 \mu \mathrm{M}$ EB and $26 \mu \mathrm{M}$ CT DNA in buffer $(150 \mathrm{mM} \mathrm{NaCl}$ and $15 \mathrm{mM}$ trisodium citrate at $\mathrm{pH}$ 7.0). The possible intercalating effect of the compounds was studied by adding a certain amount of a solution of the compound step by step into a solution of the DNA-EB complex. The influence of the addition of each compound to the DNA-EB complex solution has been obtained by recording the variation of fluorescence emission spectra with excitation wavelength at $540 \mathrm{~nm}$. The sparfloxacinato complexes 1-5 do not show any fluorescence emission at room temperature in solution or in the presence of DNA under the same experimental conditions; therefore, the observed quenching is attributed to the displacement of EB from its EBDNA complex. The values of the Stern-Volmer constant $\left(K_{\mathrm{SV}}\right.$, in $\mathrm{M}^{-1}$ ) have been calculated according to the linear SternVolmer equation (eqn (2) $)^{53}$ and the plots $\frac{I_{\mathrm{o}}}{I} v s$. [Q]. The SternVolmer equation is the following:

$$
\frac{I_{\mathrm{o}}}{I}=1+K_{\mathrm{SV}}[\mathrm{Q}]
$$

where $I_{\mathrm{o}}$ and $I$ are the emission intensities in the absence and the presence of the quencher, respectively, [Q] is the concentration of the quencher (i.e. complexes 1-5).

\section{Albumin binding experiments}

The protein binding study was performed by tryptophan fluorescence quenching experiments using bovine (BSA, $3 \mu \mathrm{M}$ ) or human serum albumin (HSA, $3 \mu \mathrm{M}$ ) in buffer (containing $15 \mathrm{mM}$ trisodium citrate and $150 \mathrm{mM} \mathrm{NaCl}$ at $\mathrm{pH}$ 7.0). The quenching of the emission intensity of tryptophan residues of BSA at $342 \mathrm{~nm}$ or HSA at $351 \mathrm{~nm}$ was monitored using complexes 1-5 as quencher with increasing concentration. The fluorescence spectra were recorded from 300 to $500 \mathrm{~nm}$ at an excitation wavelength of $295 \mathrm{~nm} .^{53}$ The sparfloxacinato complexes in buffer solutions did not exhibit under the same experimental conditions (i.e. excitation at $295 \mathrm{~nm}$ ) any fluorescence emission. The influence and the extent of the innerfilter effect on the measurements was estimated with the following formula:

$$
I_{\text {corr }}=I_{\text {meas }} \times 10^{\frac{\varepsilon\left(\lambda_{\text {exc }}\right) c d}{2}} \times 10^{\frac{\varepsilon\left(\lambda_{\text {em }}\right) c d}{2}}
$$

where $I_{\text {corr }}=$ the corrected intensity, $I_{\text {meas }}=$ the measured intensity, $c=$ the concentration of the quencher, $d=$ the cuvette ( $1 \mathrm{~cm}), \varepsilon\left(\lambda_{\text {exc }}\right)$ and $\varepsilon\left(\lambda_{\mathrm{em}}\right)=$ the $\varepsilon$ of the quencher at the excitation wavelength $(295 \mathrm{~nm})$ and the emission wavelength $(342 \mathrm{~nm}$ for BSA and $351 \mathrm{~nm}$ for HSA), respectively, as calculated from the UV-vis spectra of the complexes. ${ }^{54}$

The Stern-Volmer and Scatchard equations (eqn (4)-(6) $)^{53}$ and graphs have been used in order to study the interaction of each quencher with serum albumins and calculate the dynamic quenching constant $K_{\mathrm{SV}}$ (in $\mathrm{M}^{-1}$ ), the approximate quenching constant $k_{\mathrm{q}}$ (in $\mathrm{M}^{-1} \mathrm{~s}^{-1}$ ), the association binding constant $K$ (in $\mathbf{M}^{-1}$ ) and the number of binding sites per albumin $n$. According to the Stern-Volmer quenching equation:

$$
\frac{I_{\mathrm{o}}}{I}=1+k_{\mathrm{q}} \tau_{0}[\mathrm{Q}]=1+K_{\mathrm{SV}}[\mathrm{Q}]
$$

where $I_{\mathrm{O}}=$ the initial tryptophan fluorescence intensity of SA, $I=$ the tryptophan fluorescence intensity of SA after the addition of the quencher, $k_{\mathrm{q}}=$ the quenching rate constants of SA, $K_{\mathrm{SV}}=$ the dynamic quenching constant, $\tau_{0}=$ the average lifetime of SA without the quencher, [Q] = the concentration of the quencher, the value of $K_{\mathrm{SV}}$ can be obtained by the slope of the diagram $\frac{I_{\mathrm{o}}}{I} v s .[\mathrm{Q}]$. From the equation:

$$
K_{\mathrm{SV}}=k_{\mathrm{q}} \tau_{0}
$$

and taking $\tau_{0}=10^{-8} \mathrm{~S}$ as fluorescence lifetime of tryptophan in $\mathrm{SA}$, the value of $k_{\mathrm{q}}$ is calculated. From the Scatchard equation:

$$
\frac{\Delta I / I_{\mathrm{o}}}{[\mathrm{Q}]}=n K-K \frac{\Delta I}{I_{\mathrm{o}}}
$$

the value of $K$ is calculated from the slope in plots $\frac{\Delta I / I_{\mathrm{o}}}{[\mathrm{Q}]}$ versus $\frac{\Delta I}{I_{\mathrm{O}}}$ and $n$ is given by the ratio of $y$ intercept to the slope.

\section{Results and discussion}

\section{Synthesis and characterization of the complexes}

The complexes were synthesized via the reaction of sparfloxacin, initially deprotonated by $\mathrm{KOH}$, with $\mathrm{MnCl}_{2} \cdot 4 \mathrm{H}_{2} \mathrm{O}$ in the presence of the corresponding co-ligand $\left(N, N^{\prime}\right.$-donor $=$ 
phen, bipy, bipyam for 1-3, respectively, py for 4 and $\mathrm{H}_{2} \mathrm{O}$ for $\mathbf{5}$ ), according to the following equations:

$$
\begin{gathered}
\mathrm{MnCl}_{2} \cdot 4 \mathrm{H}_{2} \mathrm{O}+2 \mathrm{Hsf}+2 \mathrm{KOH}+N, N^{\prime} \text {-donor } \rightarrow \\
{\left[\mathrm{Mn}(\mathrm{sf})_{2}\left(N, N^{\prime} \text {-donor }\right)\right]+2 \mathrm{KCl}+6 \mathrm{H}_{2} \mathrm{O}} \\
\mathrm{MnCl}_{2} \cdot 4 \mathrm{H}_{2} \mathrm{O}+2 \mathrm{Hsf}+2 \mathrm{KOH}+2 \mathrm{py} \rightarrow \\
{\left[\mathrm{Mn}(\mathrm{sf})_{2}(\mathrm{py})_{2}\right]+2 \mathrm{KCl}+6 \mathrm{H}_{2} \mathrm{O}} \\
\mathrm{MnCl}_{2} \cdot 4 \mathrm{H}_{2} \mathrm{O}+2 \mathrm{Hsf}+2 \mathrm{KOH} \rightarrow \\
{\left[\mathrm{Mn}(\mathrm{sf})_{2}\left(\mathrm{H}_{2} \mathrm{O}\right)_{2}\right]+2 \mathrm{KCl}+4 \mathrm{H}_{2} \mathrm{O}}
\end{gathered}
$$

The resultant complexes 1-5 are soluble in DMSO and are not electrolytes; the values of the molar conductivity $\left(\Lambda_{\mathrm{M}}\right)$ of $1 \mathrm{mM}$ DMSO solution of the complexes are in the range 8-14 $\mu \mathrm{S} \mathrm{cm}^{-1}$ and indicate their non-dissociation in DMSO solution. The complexes were characterized by elemental analysis, IR and UV-vis spectroscopic techniques and magnetic measurements at room temperature. Additionally, the structure of $\mathbf{1}$ was determined by X-ray crystallography.

The deprotonation and the binding mode of sparfloxacin in complexes 1-5 were confirmed by IR spectroscopy. In the IR spectra of complexes 1-5, the band attributed to the $\nu(\mathrm{C}=\mathrm{O})_{\text {pyridone }}$ stretching vibration shifted from $1640 \mathrm{~cm}^{-1}$ in free Hsf to $1631-$ $1634 \mathrm{~cm}^{-1}$ suggesting coordination of the sparfloxacinato ligands to manganese via the pyridone oxygen. Additionally, the absence of the $\nu(\mathrm{O}-\mathrm{H})$ stretching vibration of free Hsf at 3460 (broad, medium) $\mathrm{cm}^{-1}$ was indicative of the deprotonation of its carboxylate group upon binding to metal ion. The $\nu(\mathrm{C}=\mathrm{O})_{\text {carboxyl }}$ and $\nu(\mathrm{C}-\mathrm{O})_{\text {carboxyl }}$ stretching vibrations of the carboxyl group $(-\mathrm{COOH})$ of free Hsf at 1715 (vs) $\mathrm{cm}^{-1}$ and 1292 (s) $\mathrm{cm}^{-1}$, respectively, exhibited in the spectra of the complexes a shift in the range 1598-1607 $\mathrm{cm}^{-1}$ and 1371-1384 $\mathrm{cm}^{-1}$; these bands may now be characterized as antisymmetric, $\nu_{\text {asym }}\left(\mathrm{CO}_{2}\right)$, and symmetric, $\nu_{\text {sym }}\left(\mathrm{CO}_{2}\right)$, stretching vibrations of the carboxylato group, respectively. According to the $\Delta$ values $\left[\Delta=\nu_{\text {asym }}\left(\mathrm{CO}_{2}\right)-\right.$ $\left.\nu_{\text {sym }}\left(\mathrm{CO}_{2}\right)\right]$ which appear in the range $214-233 \mathrm{~cm}^{-1}$, a monodentate coordination mode of the carboxylate group of sparfloxacinato ligands is suggested. ${ }^{55}$ Thus, the deprotonated sparfloxacinato ligands are coordinated to manganese in a bidentate mode via the pyridone oxygen and a carboxylato oxygen forming a six-membered chelate ring. ${ }^{41-44}$

The UV-vis spectra of complexes 1-5 were recorded in DMSO solution and as nujol mull and were similar showing that the compounds have the same structure in solution. The band at 375-382 $\mathrm{nm}\left(\varepsilon=250-750 \mathrm{M}^{-1} \mathrm{~cm}^{-1}\right)$ can be attributed to a charge transfer transition while the bands found in the UV region are assigned to intra-ligand transitions of the complexes. The stability and integrity of the compounds in solution may be concluded from: (i) the same UV-vis spectral features presented in solid state (nujol), in solution (DMSO) and in the presence of the buffer solution used in the biological experiments $(150 \mathrm{mM}$ $\mathrm{NaCl}, 15 \mathrm{mM}$ trisodium citrate, $\mathrm{pH}=7.0$ ), (ii) the molar conductivity measurements (8-14 $\mu \mathrm{S} \mathrm{cm}^{-1}$ in $0.1 \mathrm{mM}$ in DMSO) which suggest non-dissociation, (iii) the formation of multiple chelate rings as discussed below in the crystal structure

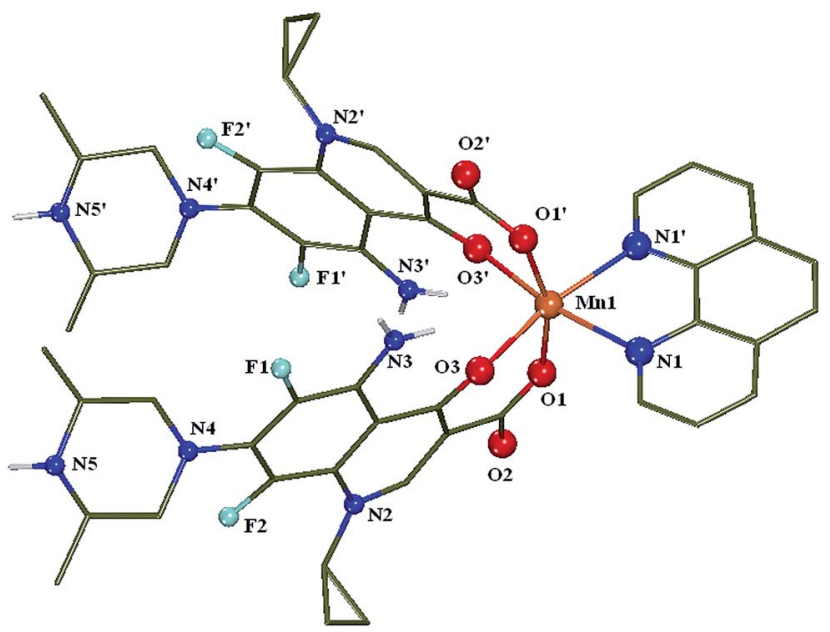

Fig. 2 A drawing of the molecular structure of 1 with only the heteroatoms labelling. Hydrogen atoms and methanol solvate molecules are omitted for clarity.

description, and (iv) the comparison with previously reported metal-quinolone complexes. ${ }^{\mathbf{1 1 , 3 8 , 3 9 , 4 1 - 4 4 , 5 6}}$

The observed values of $\mu_{\text {eff }}(=5.93-6.01 \mathrm{BM})$ for the complexes are close to the spin-only value $(=5.92 \mathrm{MB})$ at room temperature and typical for mononuclear high-spin $\mathrm{Mn}$ (II) complexes with $\mathrm{d}^{5}$ configuration $(S=5 / 2) .{ }^{57}$

\section{Structure of the complexes}

Crystal structure of complex 1-4MeOH. A drawing of the molecular structure of complex 1 is presented in Fig. 2 and selected bond distances and angles are listed in Table 2 . The complex is mononuclear and the sparfloxacinato ligands are deprotonated and bidentately bound to manganese(II) ion via the pyridone oxygen and a carboxylate oxygen. There are four methanol solvate molecules.

The Mn(II) atom, Mn(1), is six-coordinated exhibiting a distorted octahedral geometry with a $\mathrm{MnO}_{4} \mathrm{~N}_{2}$ chromophore consisted of four oxygen atoms from two sparfloxacinato ligands and two nitrogen atoms from the bidentate phen ligand occupying the six vertices of octahedron. The $\mathrm{Mn}-\mathrm{O}_{\text {carb }}$ distances

Table 2 Selected bond distances and angles for complex 1

\begin{tabular}{llll}
\hline Bond & Distance $(\AA)$ & Bond & Distance $(\AA)$ \\
\hline $\mathrm{Mn}(1)-\mathrm{O}(1)$ & $2.1190(18)$ & $\mathrm{O}(1)-\mathrm{C}(1)$ & $1.258(3)$ \\
$\mathrm{Mn}(1)-\mathrm{O}(3)$ & $2.1381(17)$ & $\mathrm{O}(2)-\mathrm{C}(1)$ & $1.254(3)$ \\
$\mathrm{Mn}(1)-\mathrm{N}(1)$ & $2.276(2)$ & $\mathrm{O}(3)-\mathrm{C}(4)$ & $1.264(3)$ \\
\hline Bond angle & $\left(^{\circ}\right)$ & Bond angle & $\left({ }^{\circ}\right)$ \\
\hline $\mathrm{O}(1)-\mathrm{Mn}(1)-\mathrm{O}\left(1^{\prime}\right)$ & $162.09(10)$ & $\mathrm{O}(3)-\mathrm{Mn}(1)-\mathrm{O}\left(3^{\prime}\right)$ & $95.44(10)$ \\
$\mathrm{O}(1)-\mathrm{Mn}(1)-\mathrm{O}(3)$ & $81.90(7)$ & $\mathrm{O}(3)-\mathrm{Mn}(1)-\mathrm{N}(1)$ & $96.12(7)$ \\
$\mathrm{O}(1)-\mathrm{Mn}(1)-\mathrm{O}\left(3^{\prime}\right)$ & $86.07(7)$ & $\mathrm{O}(3)-\mathrm{Mn}(1)-\mathrm{N}\left(1^{\prime}\right)$ & $168.42(8)$ \\
$\mathrm{O}(1)-\mathrm{Mn}(1)-\mathrm{N}(1)$ & $94.79(8)$ & $\mathrm{N}(1)-\mathrm{Mn}(1)-\mathrm{N}\left(1^{\prime}\right)$ & $72.34(11)$ \\
$\mathrm{O}(1)-\mathrm{Mn}(1)-\mathrm{N}\left(1^{\prime}\right)$ & $99.66(7)$ & &
\end{tabular}


$[\mathrm{Mn}(1)-\mathrm{O}(1)=2.1190(18) \AA]$ are close to $\mathrm{Mn}-\mathrm{O}_{\mathrm{pyr}}$ distances $[\mathrm{Mn}(1)-\mathrm{O}(3)=2.1381(17) \AA]$ and shorter than the $\mathrm{Mn}-\mathrm{N}$ distances $[\mathrm{Mn}(1)-\mathrm{N}(1)=2.276(2) \AA]$. The two pyridone oxygen atoms $\left[\mathrm{O}(3)-\mathrm{Mn}(1)-\mathrm{O}\left(3^{\prime}\right)=95.44(10)^{\circ}\right]$ are $c i s$ to each other and the two carboxylato oxygen atoms $\left[\mathrm{O}(1)-\mathrm{Mn}(1)-\mathrm{O}\left(1^{\prime}\right)=\right.$ $\left.162.09(10)^{\circ}\right]$ are in a trans arrangement. Similar arrangement of the coordinated oxygen atoms of the sparfloxacinato ligands around the metal ion (i.e. cis pyridone and trans carboxylato oxygen atoms $)^{39}$ has been also observed in the crystal structures of the complexes $\left[\mathrm{Ni}(\mathrm{sf})_{2}(\mathrm{py})_{2}\right]\left(\mathrm{O}(2)-\mathrm{Ni}(1)-\mathrm{O}(21)=89.05(6)^{\circ}\right.$ and $\left.\mathrm{O}(1)-\mathrm{Ni}-\mathrm{O}(22)=174.54(6)^{\circ}\right),{ }^{42}\left[\mathrm{Ni}(\mathrm{sf})_{2}\right.$ (phen) $]\left(\mathrm{O}(1)-\mathrm{Ni}(1)-\mathrm{O}(1)^{\prime}\right.$ $=90.78(8)^{\circ}$ and $\left.\mathrm{O}(2)-\mathrm{Ni}-\mathrm{O}(2)^{\prime}=172.26(7)^{\circ}\right),{ }^{43}$ and $\left[\mathrm{Zn}(\mathrm{sf})_{2^{-}}\right.$ (phen) $\left(\mathrm{O}(28)-\mathrm{Zn}(1)-\mathrm{O}(28)^{\prime}=94.00(12)^{\circ}\right.$ and $\mathrm{O}(27)-\mathrm{Zn}(1)-$ $\left.\mathrm{O}(27)^{\prime}=169.90(11)^{\circ}\right) .{ }^{41}$

The overall arrangement of the two sparfloxacinato ligands in the molecule could be considered as a pincer trapping the phen ligand of a neighbouring molecule creating a pair of hostguest molecules and a chain is formed (Fig. S1†), as it was previously observed and thoroughly described in the crystal structure of $\left[\mathrm{Zn}(\mathrm{sf})_{2}(\mathrm{phen})\right] .^{41}$ The host-guest structure is stabilized by the formation of a hydrogen bond between the piperazine nitrogen atom of the host molecule (donor) and the unbonded carboxylic oxygen of the sparfloxacinato ligand in the guest molecule (acceptor) (Fig. S2 $\dagger$ ). This structure is further stabilized by weak $\pi \cdots \pi[3.9982(16) \AA]$ and $\mathrm{CH} \cdots \pi$ interactions. The Mn(phen) plane of the guest molecule creates a torsion angle of about $103^{\circ}$ with the $\mathrm{Mn}$ (phen) plane of the host molecule. In the crystal lattice there are four methanol solvate molecules. Two of them are hydrogen bonded to the piperazine nitrogen atoms and additional two methanol molecules act as hydrogen bond donors to carboxylic groups and as acceptors to amino moieties of the sparfloxacinato ligands (Table S1, Fig. S2†).

The phen ligand is almost planar with the manganese atom lying in this plane. The $\mathrm{Mn}-\mathrm{N}$ bond distances $[\mathrm{Mn}(1)-\mathrm{N}(1)=$ $2.276(2) \AA]$ and the $\mathrm{N}(1)-\mathrm{Mn}(1)-\mathrm{N}\left(1^{\prime}\right)$ angle $\left[72.34(11)^{\circ}\right]$ are within the range of reported values of other chelating polycyclic $\alpha$-diimines. ${ }^{11,58,59}$

\section{Proposed structures for complexes 2-5}

Based on the experimental data (IR spectroscopy, elemental analysis, molar conductivity and magnetic measurements at ambient temperature) and after a comparison to the recent literature, we may propose a structure for complexes 2-5. Complexes $\left[\mathrm{Mn}(\mathrm{sf})_{2}(\right.$ bipy $\left.)\right], 2$ and $\left[\mathrm{Mn}(\mathrm{sf})_{2}(\right.$ bipyam $\left.)\right], 3$ are expected to have similar structure to that of complex $\mathbf{1}$, while for complexes 4 and 5 a structure similar to that of $\left[\mathrm{Ni}(\mathrm{sf})_{2}(\mathrm{py})_{2}\right],{ }^{42}$ $\left[\mathrm{Co}(\mathrm{erx})_{2}(\mathrm{py})_{2}\right]($ Herx $=$ enrofloxacin $),{ }^{60}\left[\mathrm{Zn}(\mathrm{erx})_{2}(\mathrm{py})_{2}\right],{ }^{\mathbf{6 1}}$ and $\left[\mathrm{Zn}(\mathrm{levo})_{2}\left(\mathrm{H}_{2} \mathrm{O}\right)_{2}\right]$ (Hlevo $=$ levofloxacin $)^{\mathbf{4 1}}$ is anticipated, as described below. According to the IR spectra, the sparfloxacinato ligands are deprotonated being in bidentate binding mode coordinated to manganese ion via the pyridone and a carboxylato oxygen. On the basis of the magnetic data at room temperature, the complexes are mononuclear exhibiting an octahedral geometry around $\mathrm{Mn}$ (II) ion. The octahedron is formed by four oxygen atoms of the two sparfloxacinato ligands
Table 3 Antimicrobial activity of Hsf and complexes 1-5 evaluated by MIC (in $\mu \mathrm{g} \mathrm{mL}^{-1}$ )

\begin{tabular}{lllll}
\hline Compound & B. subtilis & S. aureus & X. campestris & E. coli \\
\hline $\mathrm{Hsf}$ & 0.500 & 0.250 & 0.500 & 0.0625 \\
{$\left[\mathrm{Mn}(\mathrm{sf})_{2}(\right.$ phen $\left.)\right], \mathbf{1}$} & 0.500 & 0.500 & 0.250 & 0.0625 \\
{$\left[\mathrm{Mn}(\mathrm{sf})_{2}(\right.$ bipy $\left.)\right], 2$} & 0.250 & 0.500 & 0.500 & 0.0625 \\
{$\left[\mathrm{Mn}(\mathrm{sf})_{2}(\right.$ bipyam) $], 3$} & 1.000 & 2.000 & 1.000 & 0.125 \\
{$\left[\mathrm{Mn}(\mathrm{sf})_{2}(\mathrm{py})_{2}\right], \mathbf{4}$} & 0.250 & 0.500 & 0.500 & 0.0625 \\
{$\left[\mathrm{Mn}(\mathrm{sf})_{2}\left(\mathrm{H}_{2} \mathrm{O}\right)_{2}\right], \mathbf{5}$} & 0.250 & 0.500 & 0.500 & 0.0625
\end{tabular}

and two nitrogen or oxygen atoms from the pyridine or aqua ligands in complex $\mathbf{4}$ or $\mathbf{5}$, respectively.

\section{Antimicrobial activity of the complexes}

The antimicrobial activity of Hsf and its manganese(II) complexes 1-5 were evaluated by monitoring the growth of two Gram-positive (B. subtilis, S. aureus) and two Gram-negative (X. campestris, E. coli) bacterial strains in the presence of various concentrations of the complexes ranging from 0 to $32 \mu \mathrm{g} \mathrm{mL}{ }^{-1}$; the obtained minimum inhibitory concentration (MIC) values are presented in Table 3.
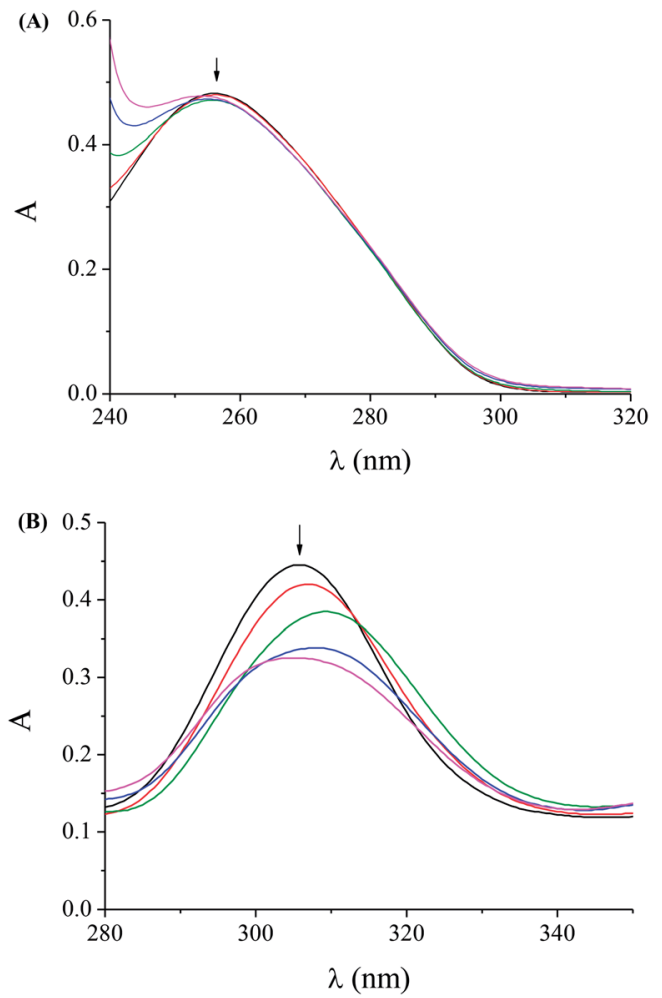

Fig. 3 (A) UV spectra of CT DNA $\left(7.5 \times 10^{-5} \mathrm{M}\right)$ in buffer solution (150 $\mathrm{mM} \mathrm{NaCl}$ and $15 \mathrm{mM}$ trisodium citrate at $\mathrm{pH}$ 7.0) in the absence or presence of $\left[\mathrm{Mn}(\mathrm{sf})_{2}(\right.$ bipyam) $], 3$. The arrow shows the changes upon increasing amounts of the complex (up to $r=0-0.6$ ). (B) UV spectra of DMSO solution $\left(1 \times 10^{-5} \mathrm{M}\right)$ of $\left[\mathrm{Mn}(\mathrm{sf})_{2}(\right.$ phen $\left.)\right], 1$ in the presence of increasing amounts of CT DNA. The arrows show the changes upon increasing amounts of CT DNA $\left(r^{\prime}=0-0.8\right)$. 
Table 4 The DNA spectral features and DNA-binding constants $\left(K_{\mathrm{b}}\right)$ of complexes $1-5$

\begin{tabular}{llr}
\hline & Band $(\lambda, \mathrm{nm})(\Delta A(\%), \Delta \lambda(\mathrm{nm}))$ & $K_{\mathrm{b}}\left(\mathrm{M}^{-1}\right)$ \\
\hline $\mathrm{Hsf}^{43}$ & $308(-12,-12)$ & $1.71( \pm 0.02) \times 10^{5}$ \\
{$\left[\mathrm{Mn}(\mathrm{sf})_{2}(\right.$ phen $\left.)\right], \mathbf{1}$} & $306(-29,-3)$ & $1.01( \pm 0.13) \times 10^{6}$ \\
{$\left[\mathrm{Mn}(\mathrm{sf})_{2}(\right.$ bipy $\left.)\right], 2$} & $304(\mathrm{sh})(-8,0)$ & $1.15( \pm 0.20) \times 10^{6}$ \\
{$\left[\mathrm{Mn}(\mathrm{sf})_{2}(\right.$ bipyam) $], 3$} & $309(-40,0)$ & $3.84( \pm 0.22) \times 10^{5}$ \\
{$\left[\mathrm{Mn}(\mathrm{sf})_{2}(\text { py })_{2}\right], \mathbf{4}$} & $303(-10,+5)$ & $1.25( \pm 0.05) \times 10^{5}$ \\
{$\left[\mathrm{Mn}(\mathrm{sf})_{2}\left(\mathrm{H}_{2} \mathrm{O}\right)_{2}\right], \mathbf{5}$} & $308(\mathrm{sh})(-6,0)$ & $3.42( \pm 0.14) \times 10^{5}$ \\
& &
\end{tabular}

The results suggest that Hsf and complexes 1-5 are active against both Gram-positive and Gram-negative bacteria with MIC values being in the range $0.0625-1.000 \mu \mathrm{g} \mathrm{mL}^{-1}$. In most cases the complexes exhibited similar or higher antimicrobial activity than free Hsf. Especially, complexes 2, 4 and 5 were more active than Hsf against B. subtilis, as well as complex 1 against $X$. campestris. On the other hand, $\left[\mathrm{Mn}(\mathrm{sf})_{2}(\right.$ bipyam) 3 was less active than Hsf against all bacteria tested. The lowest MIC values presented by all compounds were against E. coli.

The reported $\mathrm{Mn}$ (II)-quinolone complexes are rather limited up to date; thus, we cannot firmly propose the main factors that affect the antimicrobial activity according to the literature. ${ }^{11,27,39,62}$ As a first approach, among the five universally accepted factors (chelate effect of ligands, nature of ligands, nuclearity, total charge, existence and nature of counter-ions) ${ }^{63}$ responsible for the antimicrobial activity of the complexes, the chelate effect and the nature of the ligands (sparfloxacinato and $\mathrm{N}$-donor ligands) may be the prevailing factors present in complexes 1-5 that contribute to improved antimicrobial activity.

\section{Interaction of the complexes with CT DNA}

The activity of quinolone compounds as potent antibacterial agents is mainly focused on the inhibition of DNA-replication by targeting essential type II bacterial topoisomerases such as DNA gyrase and topoisomerase IV; ${ }^{27-29,64}$ thus, the evaluation of the interaction of quinolones and their complexes with DNA is of great significance. In general, metal complexes bind to double-stranded DNA via covalent (replacement of a labile ligand of the complex by a nitrogen base of DNA) or noncovalent interactions, including intercalation inside the DNA helix (via $\pi \rightarrow \pi^{*}$ stacking interaction of the complex and DNA nucleobases), groove binding along major or minor groove of the DNA helix (presence of van der Waals interaction or hydrogenbonding or hydrophobic bonding) and external/electrostatic interactions (development of Coulomb forces between metal complexes and the phosphate groups being on the surface of DNA). ${ }^{39,65,66}$

\section{Study of the DNA-binding using UV spectroscopy}

UV spectroscopy is a technique that provides useful information concerning the interaction mode and the strength of binding of complexes with DNA. In this context, the UV spectra either of a CT DNA solution $\left(C \sim 0.75-1.2 \times 10^{-4} \mathrm{M}\right)$ were recorded in the presence of the complexes 1-5 at increasing amounts (for different [complex]/[DNA] mixing ratios $(=r)$ ) or of a DMSO solution of the complexes 1-5 (1-2 $\left.\times 10^{-5} \mathrm{M}\right)$ in the presence of CT DNA at diverse $r$ values, since any interaction between the complex and CT DNA may perturb the band of CT DNA at 258$260 \mathrm{~nm}$ or the intra-ligand transition bands of the complexes, respectively, during the titrations. ${ }^{41-43}$

The UV spectra of a CT DNA solution in the presence of the complex 3 at increasing $r$ values are shown representatively in Fig. 3(A). Quite similar is the behaviour of CT DNA in the presence of the other complexes. The slight decrease of the intensity at $\lambda_{\max }=258 \mathrm{~nm}$ indicates that the interaction of CT DNA with the complex takes place resulting in the formation of a new complex with double-helical CT DNA.

In the UV spectra of complex $1\left(1 \times 10^{-5} \mathrm{M}\right)$ upon the addition of increasing amounts of CT DNA (up to $r^{\prime}=$ [DNA]/ [complex] = 1.6), the intra-ligand band at $306 \mathrm{~nm}$ (band I) shows a hypochromism up to $29 \%$ with a slight hypsochromism (Fig. 3(B) for $\left.\left(r^{\prime}=0-0.8\right)\right)$. Quite similar is the behaviour of complexes 2-5 upon the addition of CT DNA with the hypochromism being in the range $6-40 \%$ (Table 4 ). In general, the observed hypochromism may be attributed to $\pi \rightarrow \pi$ stacking interaction between the aromatic chromophore (from sparfloxacinato and/or the N-donor ligands) of the complex and DNA base pairs consistent with the intercalative binding mode. The existing results suggest that the complexes can bind to CT DNA, possibly by intercalation, although the exact mode of DNA-binding cannot be concluded only by UV spectroscopic titration studies; nevertheless, more experiments

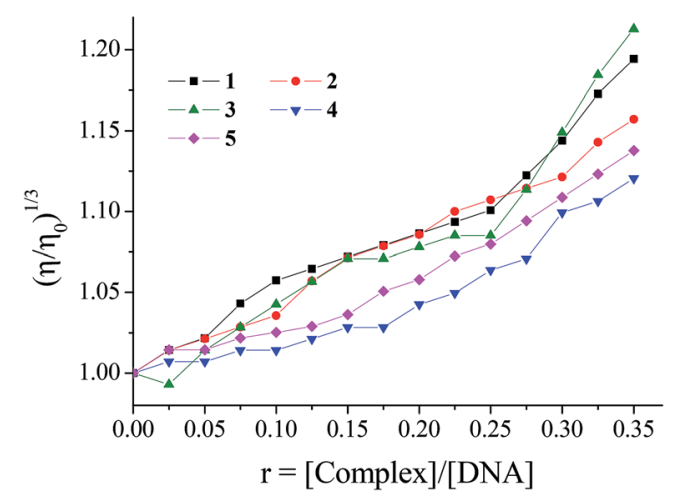

Fig. 4 Relative viscosity $\left(\eta / \eta_{0}\right)^{1 / 3}$ of CT DNA ([DNA] $\left.=0.1 \mathrm{mM}\right)$ in buffer solution (150 $\mathrm{mM} \mathrm{NaCl}$ and $15 \mathrm{mM}$ trisodium citrate at $\mathrm{pH} 7.0$ ) in the presence of complexes 1-5 at increasing amounts ( $r=$ [complex]/ [DNA]). 
are necessary in order to further clarify the binding mode and possible verify the existence of intercalation. ${ }^{67}$

The values of the DNA-binding constant $\left(K_{\mathrm{b}}\right)$ of complexes 1-5 were calculated using Wolfe-Shimer equation (eqn (1) $)^{52}$ and plots $\frac{[\mathrm{DNA}]}{\left(\varepsilon_{\mathrm{A}}-\varepsilon_{\mathrm{f}}\right)}$ versus [DNA] (Fig. S3 $\dagger$ ) and are presented in Table 4 . The $K_{\mathrm{b}}$ values are high and most of them are higher than that of free Hsf suggesting a significant increase of the $K_{\mathrm{b}}$ value when coordinated to $\mathrm{Mn}(\mathrm{II})$. The $K_{\mathrm{b}}$ values indicate a strong binding of the complexes to CT DNA, with complexes 1 and 2 having the highest $K_{\mathrm{b}}$ values $\left(=1.01( \pm 0.13) \times 10^{6} \mathrm{M}^{-1}\right.$ and $1.15( \pm 0.20) \times 10^{6} \mathrm{M}^{-1}$, respectively) among the compounds, which are higher than that of the classical intercalator EB $\left(=1.23( \pm 0.07) \times 10^{5} \mathrm{M}^{-1}\right)$ as calculated in ref. 68 . The $K_{\mathrm{b}}$ values of complexes 1 and 2 are among the highest of values of the metal-quinolone complexes reported so far. ${ }^{11,39,41-43,60,61}$

\section{DNA-binding study with viscosity measurements}

The measurement of the viscosity of a DNA solution upon addition of the complexes is a method that provides useful information in the attempt to clarify the DNA-binding mode,
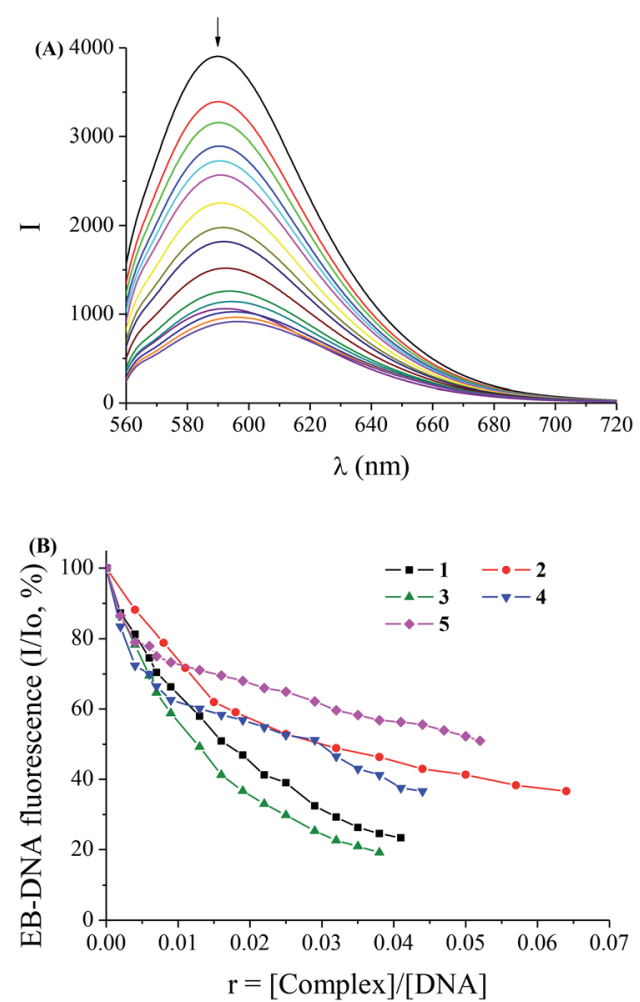

Fig. 5 (A) Emission spectra $\left(\lambda_{\text {exit }}=540 \mathrm{~nm}\right.$ ) for EB-DNA ([EB] $=20 \mu \mathrm{M}$, $[D N A]=26 \mu \mathrm{M})$ in buffer solution in the absence and presence of increasing amounts of complex 1 (up to the value of $r=0.065$ ). The arrow shows the changes of intensity upon increasing amounts of 1 . (B) Plot of EB relative fluorescence intensity at $\lambda_{\mathrm{em}}=592 \mathrm{~nm}(\%) \mathrm{vs} . r$ $(r=$ [complex]/[DNA]) (150 mM NaCl and $15 \mathrm{mM}$ trisodium citrate at $\mathrm{pH}$ $=7.0$ ) in the presence of complexes $1-5$ (up to $23 \%$ of the initial EBDNA fluorescence intensity for $1,37 \%$ for $2,19 \%$ for $3,37 \%$ for 4 and $51 \%$ for 5$)$.
Table 5 Percentage of EB-DNA fluorescence quenching $\left(\Delta / / I_{0}, \%\right)$ and Stern-Volmer constants $\left(K_{\mathrm{sv}}\right)$ for complexes $1-5$

\begin{tabular}{lll}
\hline Compound & $\begin{array}{l}\text { EB-DNA fluorescence } \\
\text { quenching, }\left(\Delta I / I_{\mathrm{o}}\right)(\%)\end{array}$ & $K_{\mathrm{SV}}\left(\mathrm{M}^{-1}\right)$ \\
\hline $\mathrm{Hsf}^{43}$ & $80 \%$ & $2.13( \pm 0.09) \times 10^{6}$ \\
{$\left[\mathrm{Mn}(\mathrm{sf})_{2}(\right.$ phen $\left.)\right], \mathbf{1}$} & $77 \%$ & $1.54( \pm 0.06) \times 10^{6}$ \\
{$\left[\mathrm{Mn}(\mathrm{sf})_{2}(\right.$ bipy $\left.)\right], 2$} & $63 \%$ & $5.13( \pm 0.21) \times 10^{5}$ \\
{$\left[\mathrm{Mn}(\mathrm{sf})_{2}(\right.$ bipyam $\left.)\right], 3$} & $81 \%$ & $2.12( \pm 0.06) \times 10^{6}$ \\
{$\left[\mathrm{Mn}(\mathrm{sf})_{2}(\mathrm{py})_{2}\right], \mathbf{4}$} & $63 \%$ & $6.61( \pm 0.17) \times 10^{5}$ \\
{$\left[\mathrm{Mn}(\mathrm{sf})_{2}\left(\mathrm{H}_{2} \mathrm{O}\right)_{2}\right], \mathbf{5}$} & $49 \%$ & $2.85( \pm 0.14) \times 10^{5}$ \\
& &
\end{tabular}

since the DNA-viscosity is quite sensitive to DNA-length changes; this relation is given by the equation $L / L_{0}=\left(\eta / \eta_{0}\right)^{1 / 3}$, with $\eta / \eta_{0}$ denoting the relative solution viscosity and $L / L_{0}$ the relative DNA length. ${ }^{65}$ In many cases, the DNA-viscosity measurements may be used complimentary to the UV spectroscopic titration studies.

In the present case, the viscosity measurements were carried out on CT DNA solutions (0.1 mM) upon addition of increasing amounts of complexes 1-5 (up to the value of $r=0.35$ ) (Fig. 4). The addition of the complexes into a DNA solution resulted in a significant increase of the relative viscosity of DNA; this increase
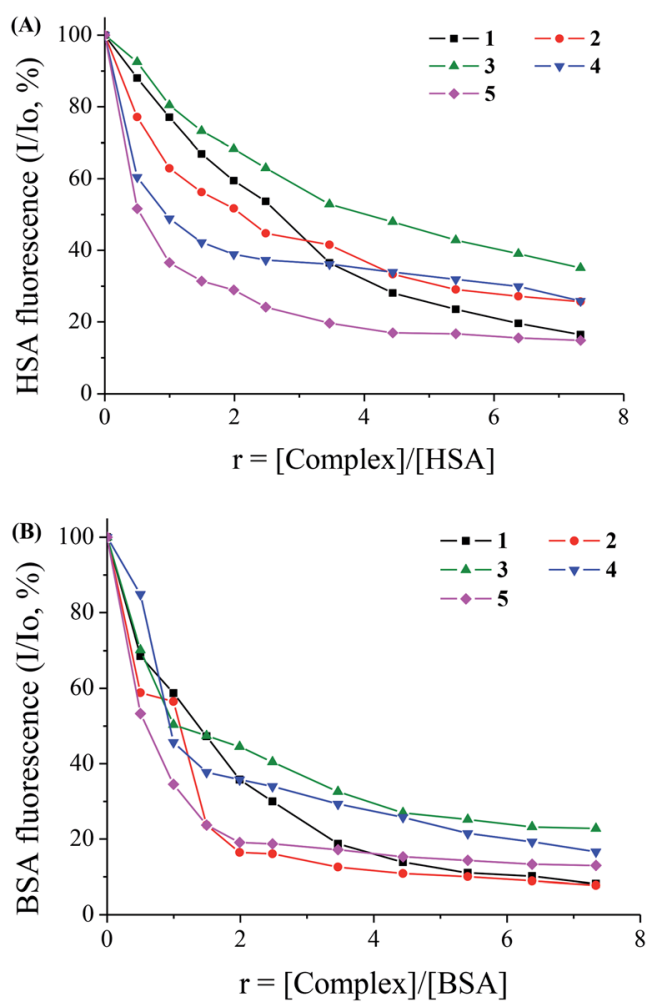

Fig. 6 (A) Plot of relative fluorescence intensity at $\lambda_{\mathrm{em}}=351 \mathrm{~nm}(\%) \mathrm{vs}$. $r(r=$ [complex]/[HSA]) for complexes $1-5$ (up to $16.5 \%$ of the initial HSA fluorescence for $1,25.5 \%$ for $2,35 \%$ for $3,25.5 \%$ for 4 and $15 \%$ for 5) in buffer solution (150 mM NaCl and $15 \mathrm{mM}$ trisodium citrate at $\mathrm{pH}$ 7.0). (B) Plot of relative fluorescence intensity at $\lambda_{\mathrm{em}}=343 \mathrm{~nm}(\%) \mathrm{vs} . r$ ( $r=$ [complex]/[BSA]) for complexes 1-5 (up to $8 \%$ of the initial BSA fluorescence for 1 and for 2, 22\% for 3,17\% for 4 and $13 \%$ for 5 ) in buffer solution ( $150 \mathrm{mM} \mathrm{NaCl}$ and $15 \mathrm{mM}$ trisodium citrate at $\mathrm{pH} 7.0$ ). 
Table 6 The BSA and HSA binding constants and parameters $\left(K_{\mathrm{sv}}, k_{\mathrm{q}}, K, n\right)$ derived for Hsf and complexes 1-5

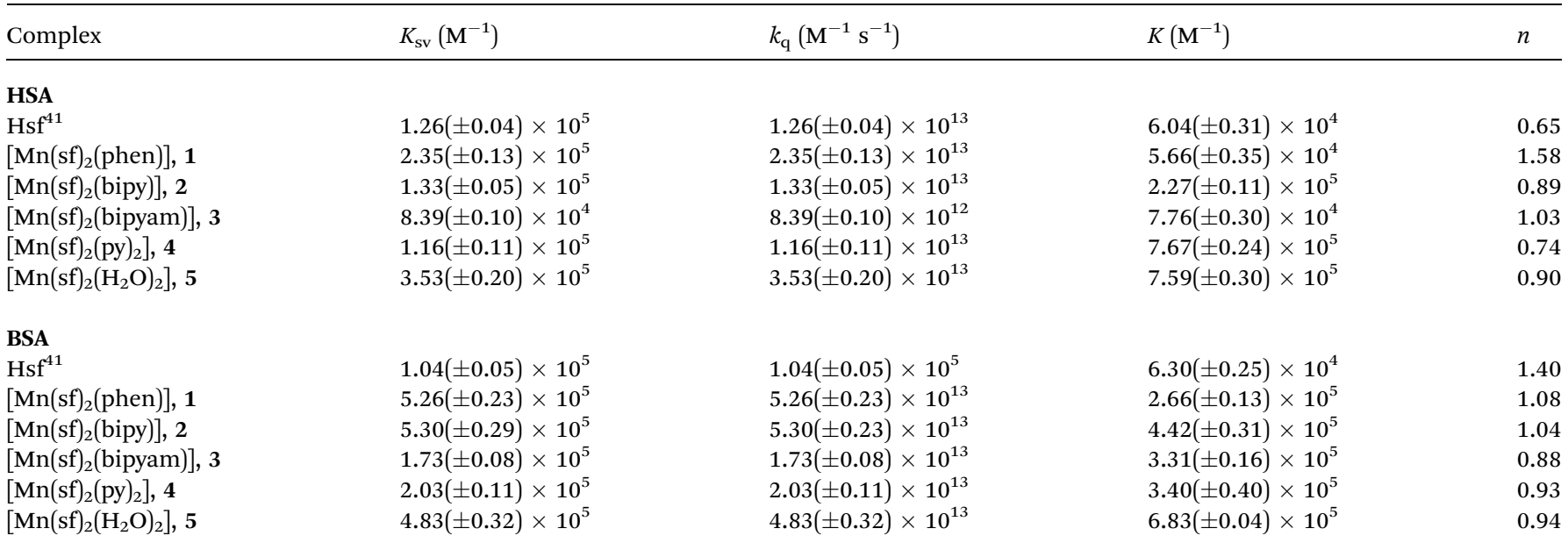

may be explained by an increase of the overall DNA length caused by the insertion of the complexes in between the DNA base pairs which increases the separation of base pairs at intercalation sites. ${ }^{41-43,65}$ The observed increase of the DNA viscosity in the presence of compounds is evidence of an intercalative binding mode to DNA; a conclusion which clarifies and enforces the preliminary findings from UV spectroscopic studies showing a hypochromism which can now be considered evidence of intercalation. ${ }^{65}$

\section{Competitive study with ethidium bromide}

Ethidium bromide (EB = 3,8-diamino-5-ethyl-6-phenylphenanthridinium bromide) intercalates to DNA through the planar EB phenanthridine ring. The result of the intercalation is the appearance of an intense fluorescence emission band at 592 $\mathrm{nm}$, when excited at $540 \mathrm{~nm}$, due to the formation of the EBDNA compound. Thus, EB is considered a typical indicator of intercalation since a quenching of the DNA-induced EB fluorescence emission may appear when an equal or stronger intercalating compound is added into a solution of the EB-DNA compound. ${ }^{69}$ Complexes 1-5 do not show any significant fluorescence emission at room temperature in solution or in the presence of CT DNA under the same experimental conditions and their addition to a solution containing EB does not provoke quenching of free EB fluorescence and new peaks do not appear in the spectra. Therefore, the changes observed in the fluorescence emission spectra of a solution containing the EB-DNA compound upon addition of the complexes can be used to investigate the ability of the complexes to displace EB from the EB-DNA complex.

The fluorescence emission spectra of pre-treated EB-DNA $([\mathrm{EB}]=20 \mu \mathrm{M},[\mathrm{DNA}]=26 \mu \mathrm{M})$ were recorded for increasing amounts of the complexes up to the value of $r=0.07$ (for 1 in Fig. 5(A)). The addition of complexes 1-5 at diverse $r$ values resulted in a moderate to significant decrease of the intensity of the emission band of the DNA-EB system at $592 \mathrm{~nm}$ (the final fluorescence is up to $19-51 \%$ of the initial EB-DNA fluorescence intensity in the presence of the complexes, Table 5) indicating a moderate to significant competition of the complexes with EB in binding to DNA (Fig. 5(B)). The observed quenching of DNAEB fluorescence by the complexes suggests that the complexes can displace EB from the DNA-EB compound, thus revealing the interaction with CT DNA by the intercalative mode. ${ }^{11,39,41-43,61,65}$

The Stern-Volmer plots of DNA-EB for complexes 1-5 (Fig. S4 $\dagger$ ) illustrate that the quenching of EB-DNA by the complexes is in good agreement $(R=0.99)$ with the linear SternVolmer equation (eqn (2)) proving that the replacement of EB from EB-DNA by each complex results in a decrease in the fluorescence intensity. ${ }^{\mathbf{4 1 - 4 3 , 6 5}}$ The obtained values of $K_{\mathrm{SV}}$ (Table 5) are relatively high showing the tight binding of the complexes to DNA with complex 3 exhibiting the highest $K_{\mathrm{sv}}$ value $\left(=2.12( \pm 0.06) \times 10^{6} \mathrm{M}^{-1}\right)$ among the complexes. The $K_{\mathrm{Sv}}$ values of complexes 1-5 are of the same magnitude to those of a series of metal complexes with quinolones as ligands. ${ }^{39}$

\section{Interaction of the complexes with serum albumins}

Serum albumin (SA) is a protein in plasma responsible for the transport of ions and drugs through the bloodstream to cells and tissues. Thus, the interaction of potential drugs with SA as a first means of their transport towards their targets in the body is worth studying for future medical use. ${ }^{4,70}$ Human serum albumin (HSA) and its homologue bovine serum albumin (BSA) were used to study the interaction with complexes 1-5 from tryptophan emission-quenching experiments. HSA has a tryptophan (Trp-214) and BSA has two tryptophans (Trp-134 and Trp-212); their solutions exhibit an intense fluorescence emission when excited at $295 \mathrm{~nm}$, with $\lambda_{\mathrm{em}, \max }=351 \mathrm{~nm}$ and 343 $\mathrm{nm}$, respectively. The sparfloxacinato complexes 1-5 did not show any significant fluorescence emission under the same experimental conditions (i.e. $\left.\lambda_{\text {exc }}=295 \mathrm{~nm}\right) .{ }^{41}$ The inner-filter effect was calculated with eqn (3) and slightly affected the measurements. ${ }^{54}$ 
The addition of complexes 1-5 to a HSA solution results in relatively significant fluorescence quenching, as calculated after the correction of the initial fluorescence spectra, (up to $\sim 85 \%$ for 5, Fig. 6(A)). The quenching of BSA fluorescence upon addition of complexes 1-5 is much more pronounced up to $\sim 92 \%$ for complexes 1 and 2 (Fig. 6(B)). This quenching may be attributed to possible changes in protein secondary structure of SA indicating the binding of the compounds to SA. ${ }^{70}$

The quenching constant values $\left(k_{\mathrm{q}}\right)$ for the interaction of complexes 1-5 with the albumins were calculated using the Stern-Volmer quenching equation (eqn (4)) and the corresponding Stern-Volmer plots (Fig. S5 and S6 $†$ ) and are given in Table 6 . The $k_{\mathrm{q}}$ values $\left(>10^{12} \mathrm{M}^{-1} \mathrm{~s}^{-1}\right)$ are higher than diverse kinds of quenchers for biopolymers fluorescence $\left(2.0 \times 10^{10}\right.$ $\mathrm{M}^{-1} \mathrm{~S}^{-1}$ ) indicating the existence of static quenching mechanism. ${ }^{71}$ These values indicate good SA quenching ability and the $k_{\mathrm{q}}$ values of the complexes are similar or higher, in most cases, than the corresponding values of free Hsf, with $\mathbf{5}$ exhibiting the highest quenching ability for HSA $\left(k_{\mathrm{q}(\mathrm{HSA}), 5}=3.53( \pm 0.20) \times\right.$ $\left.10^{13} \mathrm{M}^{-1} \mathrm{~s}^{-1}\right)$ and complexes 1 and 2 for BSA $\left(k_{\mathrm{q}(\mathrm{BSA}), \mathbf{1}}=\right.$ $5.26( \pm 0.23) \times 10^{13} \mathrm{M}^{-1} \mathrm{~s}^{-1}$ and $k_{\mathrm{q}(\mathrm{BSA}), 2}=5.30( \pm 0.23) \times 10^{13}$ $\left.\mathrm{M}^{-1} \mathrm{~S}^{-1}\right)$. The values of the quenching constants are within the range found for a series of metal-quinolone complexes. ${ }^{39}$

The values of the association binding constant $(K)$ of the complexes to the SAs were calculated using the Scatchard equation (eqn (6)) and the corresponding Scatchard plots (Fig. S7 and S8 $\dagger$ ) and are given in Table 6 . The $K$ values of complexes 1-5 are relatively high and higher than that of free Hsf with complexes 4 and 5 having the highest $K$ value for HSA $\left(K_{(\mathrm{HSA}), 4}=7.67( \pm 0.24) \times 10^{5} \mathrm{M}^{-1}, K_{(\mathrm{HSA}), 5}=7.59( \pm 0.30) \times 10^{5}\right.$ $\mathbf{M}^{-1}$ ), while in the case of BSA complex 5 exhibits the highest $K$ value among the compounds $\left(K=6.83( \pm 0.04) \times 10^{5} \mathrm{M}^{-1}\right)$. Comparing the affinity of the complexes for BSA and HSA ( $K$ values), it is obvious that all complexes except 4 show higher affinity for BSA than HSA. In general, the $K$ values of the complexes are of the same magnitude with those calculated for a series of metal-quinolone complexes. ${ }^{39}$

In general, the values of the binding constants $(K)$ of the complexes to SA are in the range $5.66( \pm 0.35) \times 10^{4}$ to $7.67( \pm 0.24) \times 10^{5} \mathrm{M}^{-1}$ which could be considered rather optimum suggesting their binding to SAs and possible transfer. All the $K$ values are significantly lower than the value of the association constant of the protein avidin with diverse compounds $\left(K \approx 10^{15} \mathrm{M}^{-1}\right.$ ), an interaction which is considered the strongest known non-covalent one $;^{72,73}$ indeed, the binding constants are reasonably low so that the complexes can get reversibly released when arriving at their targets.

\section{Conclusions}

The synthesis and characterization of the mononuclear manganese(II) complexes with the third-generation quinolone antibacterial agent sparfloxacin in the absence or presence of the nitrogen-donor heterocyclic ligands 1,10-phenanthroline, 2,2'bipyridine, 2,2'-bipyridylamine or pyridine was successfully achieved. In the resultant complexes, sparfloxacinato ligands are deprotonated being bidentately coordinated to manganese via the pyridone and a carboxylato oxygen. The crystal structure of the complex $\left[\mathrm{Mn}(\mathrm{sf})_{2}\right.$ (phen)] was determined by X-ray crystallography revealing a distorted octahedral geometry for $\mathrm{Mn}$ (II) presenting a similar arrangement of the atoms around manganese with previously reported $\mathrm{Zn}$-sparfloxacinato complexes.

UV spectroscopy studies and viscosity measurements were employed to investigate the interaction of the complexes with CT DNA. Complexes $\left[\mathrm{Mn}(\mathrm{sf})_{2}\right.$ (phen)], 1 and $\left[\mathrm{Mn}(\mathrm{sf})_{2}(\right.$ bipy $\left.)\right], 2$, exhibit the highest DNA binding constants, $K_{\mathrm{b}}\left(K_{\mathrm{b}(\mathbf{1})}=\right.$ $1.01( \pm 0.13) \times 10^{6} \mathrm{M}^{-1}$ and $K_{\mathrm{b}(2)}=1.15( \pm 0.20) \times 10^{6} \mathrm{M}^{-1}$, respectively), among the complexes examined, which are among the highest values of the reported metal-quinolone complexes ${ }^{39}$ and higher than the $K_{\mathrm{b}}$ value of EB as calculated in our lab. ${ }^{68}$ Competitive binding studies with EB revealed the significant EB-displacing ability of the complexes from the EB-CT DNA complex indicating indirectly the intercalation as the most possible interaction mode to CT DNA, a conclusion which is in accordance to the viscometry measurements.

The antimicrobial activity of the complexes was estimated by MIC determination; in most cases and with the exception of complex 3, the complexes show similar or slightly better activity than free Hsf against the bacteria tested.

The interaction of all complexes with bovine or human serum albumins was studied using fluorescence emission spectroscopy. The complexes bind to both albumins BSA and HSA and have relatively high binding constants, $K$; the $K$ values are in the range $5.66 \times 10^{4}$ to $7.67 \times 10^{5} \mathrm{M}^{-1}$ and are indicative of the complexes' ability to bind to the albumin in order to get transferred towards their targets where they can get released since the $K$ values are not too high.

In conclusion, the existing biological studies concerning the Mn(II)-sparfloxacinato complexes 1-5 are promising in regard to their potential application as antimicrobial agents; although the antibacterial activity of the complexes is similar or slightly higher than free Hsf, it is significant since the MIC values are very low.

\section{Abbreviations}

$\begin{array}{ll}\begin{array}{l}\text { B. subtilis } \\ \text { bipy }\end{array} & \text { Bacillus subtilis } \\ \text { bipyam } & \text { 2,2'-Bipyridine } \\ \text { BSA } & \text { Bovine serum albumin } \\ \text { CT } & \text { Calf-thymus } \\ \text { DMF } & N, N \text {-Dimethylformamide } \\ \text { DMSO } & \text { Dimethylsulfoxide } \\ \text { E. coli } & \text { Escherichia coli } \\ \text { EB } & \text { Ethidium bromide =3,8-diamino-5-ethyl-6- } \\ & \text { phenyl-phenanthridinium bromide } \\ \text { Herx } & \text { Enrofloxacin } \\ \text { Hlevo } & \text { Levofloxacin } \\ \text { Hsf } & \text { Sparfloxacin = 5-amino-1-cyclopropyl-7-(cis-3,5- } \\ & \text { dimethyl-1-piperazinyl)-6,8-difluoro-1,4-dihydro- } \\ & \text { 4-oxo-3-quinolinecarboxylic acid } \\ \text { HSA } & \text { Human serum albumin }\end{array}$




$\begin{array}{ll}\text { MIC } & \text { Minimum inhibitory concentration } \\ \text { phen } & 1,10 \text {-Phenanthroline } \\ \text { py } & \text { Pyridine } \\ r & \text { [Compound]/[CT DNA] mixing ratios } \\ r^{\prime} & \text { [DNA]/[complex] mixing ratios } \\ \text { s } & \text { Strong } \\ \text { S. aureus } & \text { Staphylococcus aureus } \\ \text { SA } & \text { Serum albumin } \\ \text { sf } & \text { Sparfloxacinato anion } \\ \text { sh } & \text { Shoulder } \\ \text { vs } & \text { Very strong } \\ X . \text { campestris } & \text { Xanthomonas campestris } \\ \Delta & \nu_{\text {asym }}\left(\mathrm{CO}_{2}\right)-\nu_{\text {sym }}\left(\mathrm{CO}_{2}\right)\end{array}$

\section{Acknowledgements}

This research has been co-financed by European Social Fund (ESF) and Greek national funds (National Strategic Reference Framework (NSRF): Archimides III. This project was supported by EU COST Action CM1105, the Slovenian Research Agency (ARRS) through project P1-0175 and partially by the infrastructure of the EN-FIST, Center of Excellence, Ljubljana, Slovenia.

\section{References}

1 E. J. Larson and V. L. Pecoraro, in Manganese Enzymes, ed. V. L. Pecoraro, VCH Publishers Inc, New York, 1992, pp. 1-28.

2 C. S. Mullins and V. L. Pecoraro, Coord. Chem. Rev., 2008, 252, 416-443.

3 Z. Guo and P. J. Sadler, Angew. Chem., Int. Ed., 1999, 38, 15121531.

4 M. Li, C. Chen, D. Zhang, J. Niu and B. Ji, Eur. J. Med. Chem., 2010, 45, 3169-3177.

5 D. Zhou, Q. Chen, Y. Qi, H. Fu, Z. Li, K. Zhao and J. Gao, Inorg. Chem., 2011, 50, 6929-6937.

6 X. Chen, L. Tang, Y. Sun, P. Qiu and G. Liang, J. Inorg. Biochem., 2010, 104, 1141-1147.

7 D. P. Singh, K. Kumar and C. Sharma, Eur. J. Med. Chem., 2010, 45, 1230-1236.

8 P. Dorkov, I. N. Pantcheva, W. S. Sheldrick, H. Mayer-Figge, R. Petrova and M. Mitewa, J. Inorg. Biochem., 2008, 102, 2632.

9 M. S. Refat, J. Mol. Struct., 2013, 1037, 170-185.

10 M. G. A. El-Wahed, M. S. Refat and S. M. El-Megharbel, J. Mol. Struct., 2008, 892, 402-413.

11 M. Zampakou, M. Akrivou, E. G. Andreadou, C. P. Raptopoulou, V. Psycharis, A. A. Pantazaki and G. Psomas, J. Inorg. Biochem., 2013, 121, 88-99.

12 S. Mandal, A. Rout, A. Ghosh, G. Pilet and D. Bandyopadhyay, Polyhedron, 2009, 28, 3858-3862.

13 G. Kumar, S. Devi, R. Johari and D. Kumar, Eur. J. Med. Chem., 2012, 52, 269-274.

14 M. Patil, R. Hunoor and K. Gudasi, Eur. J. Med. Chem., 2010, 45, 2981-2986.
15 R. F. M. Elshaarawy and C. Janiak, Eur. J. Med. Chem., 2014, 75, 31-42.

16 B. S. Creaven, D. A. Egan, D. Karcz, K. Kavanagh, M. McCann, M. Mahon, A. Noble, B. Thati and M. Walsh, J. Inorg. Biochem., 2007, 101, 1108-1119.

17 I. Georgieva, T. Mihaylov and N. Trendafilova, J. Inorg. Biochem., 2014, 135, 100-112.

18 R. B. Dixit, S. F. Vanparia, T. S. Patel, C. L. Jagani, H. V. Doshi and B. C. Dixit, Appl. Organomet. Chem., 2010, 24, 408-413.

19 N. Nishat, T. Ahamad, S. M. Alshehri and S. Parveen, Eur. J. Med. Chem., 2010, 45, 1287-1294.

20 T. A. Yousef, G. M. A. El-Reash, M. Al-Jahdali and E. R. ElRakhawy, J. Mol. Struct., 2013, 1053, 15-21.

21 M. Devereux, M. McCann, V. Leon, R. Kelly, D. O. Shea and V. McKee, Polyhedron, 2003, 22, 3187-3194.

22 N. J. S. Costa, C. R. Bombardieri, J. S. Kuribayashi, M. M. de Camargo, L. H. Andrade, E. Kagohara and B. P. Esposito, Chem. Biodiversity, 2008, 5, 2156-2159.

23 L. Jin, F. Xiao, G. Cheng and Z. Ji, Inorg. Chem. Commun., 2006, 9, 758-760.

24 L. Jin, F. Xiao, G. Cheng and Z. Ji, J. Organomet. Chem., 2006, 691, 2909-2914.

25 D. P. Singh, K. Kumar and C. Sharma, Eur. J. Med. Chem., 2009, 44, 3299-3304.

26 R. V. Singh and A. Chaudhary, J. Inorg. Biochem., 2004, 98, 1712-1721.

27 I. Turel, Coord. Chem. Rev., 2002, 232, 27-47 and references cited therein.

28 The Quinolones, ed. V. T. Andriole, Academic Press, 2000.

29 D. E. King, R. Malone and S. H. Lilley, Am. Fam. Physician, 2000, 61, 2741-2748.

30 J. H. Morais Cabral, A. P. Jackson, C. V. Smith, N. Shikotra, A. Maxwell and R. C. Liddington, Nature, 1997, 388, 903-906.

31 M. E. Katsarou, E. K. Efthimiadou, G. Psomas, A. Karaliota and D. Vourloumis, J. Med. Chem., 2008, 51, 470-478.

32 I. Turel, J. Kljun, F. Perdih, E. Morozova, V. Bakulev, N. Kasyanenko, J. A. W. Byl and N. Osheroff, Inorg. Chem., 2010, 49, 10750-10752.

33 J. Kljun, A. K. Bytzek, W. Kandioller, C. Bartel, M. A. Jakupec, C. G. Hartinger, B. K. Keppler and I. Turel, Organometallics, 2011, 30, 2506-2512.

34 I. Turel, A. Golobic, A. Klavzar, B. Pihlar, P. Buglyo, E. Tolis, D. Rehder and K. Sepcic, J. Inorg. Biochem., 2003, 95, 199207.

35 M. P. Lopez-Gresa, R. Ortiz, L. Perello, J. Latorre, M. LiuGonzalez, S. Garcia-Granda, M. Perez-Priede and E. Canton, J. Inorg. Biochem., 2002, 92, 65-74.

36 N. Jimenez-Garrido, L. Perello, R. Ortiz, G. Alzuet, M. Gonzalez-Alvarez, E. Canton, M. Liu-Gonzalez, S. Garcia-Granda and M. Perez-Priede, J. Inorg. Biochem., 2005, 99, 677-689.

37 P. Drevensek, I. Turel and N. Poklar Ulrih, J. Inorg. Biochem., 2003, 96, 407-415.

38 K. C. Skyrianou, F. Perdih, I. Turel, D. P. Kessissoglou and G. Psomas, J. Inorg. Biochem., 2011, 104, 63-74.

39 G. Psomas and D. P. Kessissoglou, Dalton Trans., 2013, 42, 6252-6276. 
40 Meyler's Side Effects of Drugs: The International Encyclopedia of Adverse Drug Reactions and Interactions, in Sparfloxacin, ed. J. K. Aronson, Elsevier, 2006, pp. 31723174.

41 A. Tarushi, E. Polatoglou, J. Kljun, I. Turel, G. Psomas and D. P. Kessissoglou, Dalton Trans., 2011, 40, 9461-9473.

42 K. C. Skyrianou, C. P. Raptopoulou, V. Psycharis, D. P. Kessissoglou and G. Psomas, Polyhedron, 2009, 28, 3265-3271.

43 K. C. Skyrianou, E. K. Efthimiadou, V. Psycharis, A. Terzis, D. P. Kessissoglou and G. Psomas, J. Inorg. Biochem., 2009, 103, 1617-1625.

44 E. K. Efthimiadou, Y. Sanakis, C. P. Raptopoulou, A. Karaliota, N. Katsaros and G. Psomas, Bioorg. Med. Chem. Lett., 2006, 16, 3864-3867.

45 D. Shingnapurkar, R. Butcher, Z. Afrasiabi, E. Sinn, F. Ahmed, F. Sarkar and S. Padhye, Inorg. Chem. Commun., 2007, 10, 459-462.

46 C. Tan, J. Liu, H. Li, W. Zheng, S. Shi, L. Chen and L. Ji, J. Inorg. Biochem., 2008, 102, 347-358.

47 J. Marmur, J. Mol. Biol., 1961, 3, 208-211.

48 M. F. Reichmann, S. A. Rice, C. A. Thomas and P. Doty, J. Am. Chem. Soc., 1954, 76, 3047-3053.

49 Agilent, CrysAlis PRO, Agilent Technologies, Yarnton, Oxfordshire, England, 2013.

50 G. M. Sheldrick, Acta Crystallogr., Sect. A: Found. Crystallogr., 2008, 64, 112-122.

51 J. M. Andrews, J. Antimicrob. Chemother., 2001, 48(suppl. S1), 5-16.

52 A. Wolfe, G. Shimer and T. Meehan, Biochemistry, 1987, 26, 6392-6396.

53 Y. Wang, H. Zhang, G. Zhang, W. Tao and S. Tang, J. Lumin., 2007, 126, 211-218.

54 L. Stella, A. L. Capodilupo and M. Bietti, Chem. Commun., 2008, 4744-4746.

55 K. Nakamoto, Infrared and Raman Spectra of Inorganic and Coordination Compounds, Part B: Applications in Coordination, Organometallic, and Bioinorganic Chemistry, Wiley, New Jersey, 6th edn, 2009.
56 M. Zampakou, N. Rizeq, V. Tangoulis, A. N. Papadopoulos, F. Perdih, I. Turel and G. Psomas, Inorg. Chem., 2014, 53, 2040-2052.

57 B. Chiswell, E. D. McKenzie and L. F. Lindoy, in Comprehensive Coordination Chemistry, ed. G. Wilkinson, Pergamon Press, Oxford, 1987, vol. 4, pp. 1-122.

58 B. A. Frenz and J. A. Ibers, Inorg. Chem., 1972, 11, 1109-1116.

59 A. Grirrane, A. Pastor, A. Ienco, C. Mealli and A. Galindo, J. Chem. Soc., Dalton Trans., 2002, 3771-3777.

60 C. Protogeraki, E. G. Andreadou, F. Perdih, I. Turel, A. A. Pantazaki and G. Psomas, Eur. J. Med. Chem., 2014, 86, 189-201.

61 A. Tarushi, G. Psomas, C. P. Raptopoulou, V. Psycharis and D. P. Kessissoglou, Polyhedron, 2009, 28, 3272-3278.

62 V. Uivarosi, Molecules, 2013, 18, 11153-11197.

63 A. D. Russell, in Disinfection, Sterilization and Preservation, ed. S. S. Block, Lippincott Williams \& Wilkins, Philadelphia, 5th edn, 2001, pp. 31-56.

64 N. Ahmed, M. Dawson, C. Smith and E. Wood, Biology of Disease, Taylor \& Francis, 2007, ch. 3, pp. 41-71.

65 J. Kljun, I. Bratsos, E. Alessio, G. Psomas, U. Repnik, M. Butinar, B. Turk and I. Turel, Inorg. Chem., 2013, 52, 9039-9052.

66 M. M. Aleksic and V. Kapetanovic, Acta Chim. Slov., 2014, 61, 555-573.

67 G. Pratviel, J. Bernadou and B. Meunier, Adv. Inorg. Chem., 1998, 45, 251-262.

68 A. Dimitrakopoulou, C. Dendrinou-Samara, A. A. Pantazaki, M. Alexiou, E. Nordlander and D. P. Kessissoglou, J. Inorg. Biochem., 2008, 102, 618-628.

69 W. D. Wilson, L. Ratmeyer, M. Zhao, L. Strekowski and D. Boykin, Biochemistry, 1993, 32, 4098-4104.

70 J. R. Lakowicz, Principles of Fluorescence Spectroscopy, Springer, New York, 3rd edn, 2006.

71 W. D. Wilson, L. Ratmeyer, M. Zhao, L. Strekowski and D. Boykin, Biochemistry, 1993, 32, 4098-4104.

72 O. H. Laitinen, V. P. Hytonen, H. R. Nordlund and M. S. Kulomaa, Cell. Mol. Life Sci., 2006, 63, 2992-3017.

73 V. Rajendiran, R. Karthik, M. Palaniandavar, H. StoeckliEvans, V. S. Periasamy, M. A. Akbarsha, B. S. Srinag and H. Krishnamurthy, Inorg. Chem., 2007, 46, 8208-8221. 